\title{
Preface to the French edition
}

I was moved to prepare this edition of Professor Antonio Truyol y Serra's brief but excellent work on the foundations of the law of nations by my desire to discharge an intellectual debt to this masterly Spanish teacher and thinker, having died on 1 October 2003. The present edition bears affectionate posthumous witness to the many ways in which I am intellectually indebted to him.

It is worth mentioning that, some ten years ago, I wanted to devote my doctoral thesis to the theoretical foundations of international law. At that time I abandoned the idea, because I did not yet feel equal to the task. But I resolved to return to it. Subsequently, having become aware of Truyol's book on the Doctrines contemporaines du droit des gens, I found it difficult to envisage writing a monograph on the same subject, since, on a great number of points, I would have found myself repeating what he had already said, and doing so in less impressive terms. Not long ago, it occurred to me simply to re-edit and at the same time develop Truyol's Doctrines of 1951, bringing it up to date and consolidating it with the contents of his General Course at the Hague Academy. Readers must judge for themselves how well I have achieved this aim. The task has given me enormous intellectual pleasure as I immersed myself, day and night in the fascinating world of fundamental legal thinking. Perhaps I may also be allowed a more personal observation. In the course of my work I was struck by the fact that twice, when trying to locate passages that Don Antonio had cited without giving the exact reference, I 'happened' to open the relevant book, containing several hundred references, at exactly the right page, so that my gaze fell instantly on the passage I was looking for. Perhaps it was a sign that Don Antonio was actively forwarding my work ...

$$
\text { *** } *
$$

How does one even begin to address the theoretical foundations of law in its entirety, and of international law in particular? One has to start by considering the relationship between the sources of law and law's actual foundations, its basis. 
(a) Investigation of the sources concerns the question 'How?': how was and is law created, and what are the applicable categories? How does a society come to recognise that any particular rule is a legal one? There are two distinct aspects to this. The first relates to the deliberate creation of law, the model method being legislation. The second aspect concerns a society's spontaneous creation of law, for example by way of custom. We need also to realise that the question of sources can be considered in either an active or a passive perspective. The active aspect focuses on the process by which rules are generated (Erzeugungsarten), whereas the passive aspect describes the normative categories within which the relevant rule makes its appearance, i.e. identifies where the rule can be found once it has come into existence (Erscheinungsformen). These are most often two sides of the same coin - the act of production, and the finished product. The doctrine of sources thus relates back to the facts of reality, to a sociological process. Sources are a rationalisation of normative facts, because they describe the manner in which law is generated by those who have the power to make rules for the society in question.

(b) The basis or foundation of the law poses a quite different question, namely 'Why?': why should one obey the law and the rule of law? What is its justification? Presented in these terms, the question goes to the root of the phenomenon that is law, and to the sense of its role in this world. Few questions can be more profound or more serious. The distinction between the foundational question and the sources question is an obvious one. We may know how a rule came into being, but that may tell us nothing about the justification for it. Ultimately, the law, in this regard, has a higher reach than sociology, into the realm of the metaphysical. Here we are no longer concerned with normative facts, or with the description of causative forces, but rather with normative reasons; we are considering ends, finalities, from a value-related (axiological) perspective. In a wider sense, the question of the basis of law encompasses the entire metaphysics of the subject, the entire quest for the requirements of justice (or other) through law, whether in law generally or in any particular legal order of things. Here we are mainly brought face to face with the ancient idea of just law, droit juste, or richtiges Recht. In this specific sense, the question of the basis or foundation of law is always a critical one: it involves a conception of some ideal which has to be brought to bear in order to assess and judge any concrete law, thus giving the measure of the subsequent efforts that need to be made; it involves the perpetually doubting mind in examining its concrete legal creations in space and time; and it undermines all false certainties and makes it impossible to relax into the easy complacency of mere technique. 
What, then, is the theoretical foundation of law? Why must we respect the rule of law? In summary, there are three ways of conceiving of this foundation, each providing a different answer, both in relation to the general theory of law, and in relation to international law in particular. Law can be considered from the perspectives of value, of validity, and of effectivity. ${ }^{1}$ Its foundation can therefore be perceived in a transcendent value (natural law); or in its having been decreed and sanctioned by the powers that be (positivism); or in the simple fact that it operates effectively within the society concerned (sociologism). That, moreover, is the order in which the various doctrines historically emerged. ${ }^{2}$ Natural law was already recognised in Antiquity. As early as one of the first fragments recovered from Greek times, by Anaximander of Miletus, a superior order was postulated, a cosmos made manifest in the being of the world. The jus naturalist doctrine was then developed further, particularly by the Stoa. Positivism, by contrast, arose at the dawn of the modern age, although to the extent that it involves an appeal to will, it is much older than that. Will had been postulated as a source of law by the later Roman emperors, particularly the Byzantines. It was also supported by theology, for example by the Franciscans, following St. Paul, who saw God as an all-powerful legislator. If we were to liken western legal thinking to a single great fugue, we could regard the dispute about the foundation of law, between reason (natural law) and will (voluntarism), as that fugue's unchanging theme. ${ }^{3}$ And then, finally, we have the sociological theories, whose origins are more recent, emerging only in the late nineteenth century. They take new ideas in the natural sciences to their ultimate conclusions, linking the observation of facts to causative laws.

For convenience, we will give a short preliminary consideration to these three approaches to the foundations of law in inverse historical order, starting with positivist doctrine, then considering sociological doctrine, and completing the exercise with an examination of natural law doctrine ${ }^{4}$ The aim is to provide a short but hopefully dense introductory discussion on the issue of law's foundation in general, before plunging

1 See e.g., L. Lombardi Vallauri, Corso di filosofia del diritto, Padova, 1981, pp. 144 et seq.

2 On the historical shaping of the doctrines, see e.g., J. M. Kelly, A Short History of Western Legal Theory, Oxford, 1992.

3 Cf. H. Welzel, Naturrecht und materiale Gerechtigkeit, 4th edn., Göttingen, 1990. G. Fassò, La legge della ragione, Bologna, 1964.

4 See also R. Kolb, Theory of International Law, Oxford/Portland, 2016, pp. 99 et seq. 
into the specific area of international law, which is the subject-matter of the present monograph.

\section{LEGAL POSITIVISM}

Legal positivism ${ }^{5}$ is a relatively recent doctrine, some of whose roots can be traced back to the relativism of the Sophists and the nominalism ${ }^{6}$ of mediaeval times. The leading nominalists included Duns Scotus, William of Ockham, P. D’Ailly, J. Gerson, G. Biel, and F. (not Gabriel!) Vasquez. For these authors, reality resided not in general concepts, but only in individual objects. They therefore concluded that the source of all duties was to be found not in reason, which is a general concept, but in the will of God, which is a concrete reality. This doctrine, when applied to legal duties, has a multiplicative effect: there are as many laws as there are individual wills intent on creating them; and above all, there is no general or common law. Here, then, Thomist reductio ad unum became a reductio ad plurium, opening the way to an atomistic and causal conception of the world.

Modern legal positivism, for its part, emerged in response to three stimuli: the impact of reform, which blew apart many ancient unitary values; fascination with the exact methods of the natural sciences; and the consolidation, within the modern State, of absolute centralised power. This was the period in which man began to place himself at the centre of

5 See e.g., N. Bobbio, Il positivismo giuridico, Turin, 1996; C. Grzegorczyk, F. Michault and M. Troper, Le positivism juridique, Paris/Brussels, 1993; E. J. Lampe, Grenzen des Rechtspositivismus, Berlin, 1988; Centre de philosophie politique et juridique de l'Université de Caen (ed.), Cahiers de philosophie politique et juridique, no 13, Du positivisme juridique, Caen, 1988; W. Ott, Der Rechtspositivismus, Berlin, 1976; U. Scarpelli, Cos'è il positivismo giuridico, Milan, 1965; S. I. Shuman, Legal Positivism, Its Scope and Limitations, Detroit, 1963; G. Lumia, Empirismo logico e positivismo giuridico, Milan, 1963. See further: M. Kramer, In Defense of Legal Positivism: Law without Trimmings, Oxford, 1999; W. J. Waluchow, Inclusive Legal Positivism, Oxford, 1994. For a short contribution, see e.g., E. Maulin, 'Positivisme', in: D. Alland/S. Rials (eds), Dictionnaire de la culture juridique, Paris, 2003, pp. 1171 et seq.

6 For nominalists, existence preceded essence: there are no such things as general concepts or ideas: all ideas are realised in the concrete objects of this world. In this way, nominalism prepared the way for positivism: if there is no general essence, universal natural law cannot exist. There can be only particular laws, based simply on the will of the legislator. 
the cosmos, a tendency initiated by Renaissance humanism. That tendency was to lead to the philosophical and legal idealism of the Germans and Italians, notably through a strong influence of Hegelianism. From this perspective, reality is to be found entirely within the individual consciousness (subjective idealism) or in the governing spirit of the world (objective idealism). This spirit is realised in individualities such as, for example, the State. The outer world is a projection of the consciousness and will of the single subjects. Here, then, the will of these individual subjects, in particular the State, becomes the supreme source of law, indeed its very foundation. Law is no longer transcendent; it has become immanent, the product of intelligent human will. Positivism received its strongest imprint from the new causative methods of the natural sciences, which replaced the teleological and theological conceptions of mediaeval times.

The common root of the various positive positions resides in their rejection of metaphysics. Everything has to be brought down to observable facts, data that are purely objective as the fruits of realities. Positivism therefore recognises only individual facts, such as, for example a particular law enacted on a particular date. It sets its face against general essences or values that cannot be subjected to observation. Thus, it turns its back on the idea of natural law, which cannot be scientifically proven to exist. As a result, positivism has certain characteristic features, namely individualism, empiricism, relativism, statism, voluntarism, and, last but not least, formalism. ${ }^{7}$ What then about values? Since values are not observable facts, but matters of personal opinion, they are irrational and cannot be more than the subject-matter of radically subjective judgments. The consequence is that one has to eliminate all material values as foundations for the law (not necessarily as assets for the interpretation of the positive law), because, if they were taken into account, it would be equivalent to constructing the edifice of positive law on speculative subjective foundations. For this reason, positivists consider the actual content of the legal norm is, so to speak, a matter of indifference. The choice of the values which a law is designed to serve is

7 An eminent Italian author identified the fundamental postulates of legal positivism as follows: (i) the law is based on facts and not on values; (ii) law supposes coercion; (iii) law is concentrated in its primary source, legislation; (iv) the norm is a command (imperativistic theory of the law); (v) the legal order is coherent and complete in itself, there are no contradictions and no gaps; (vi) legal interpretation is mechanistic and only declares preexisting positions; (vii) there is an absolute duty of obeyance to the formal legal enactment ('Gesetz is Gesetz'). See Bobbio, supra note 5, pp. 127 et seq. 
no more than a matter of subjective judgment; it is a matter for the free will of the legislator. It follows that, for what one may call the science of the law, the only determining feature is the form by which the law is made, not its content. Only the form can give rise to an objective judgment. The law is reduced to an allgemeine Rechtslehre, to an explanation of competences and of the techniques for the creation, interpretation and application of its rules. Here, then, we are dealing with a gigantic piece of clockwork, controlling the law as a clock controls the recording of time, and without ever concerning itself with the source of energy that set the entire system in motion.

Briefly, positivism postulates that every law and every norm, provided it has been created in whatever due form is required, is valid as a matter of logical necessity. Furthermore, all the law there is, is to be found in the laws duly created by the relevant mechanism, and everything enacted by the mechanism is law. Law is thus directly identified with the State, which alone has the competence to create law, doing so by the exercise of its will. To question the foundations of law is no longer necessary, and indeed, from the legal perspective, makes no sense. The basis of law is identified as lying exclusively in its source. As regards the relationship between foundations and sources, the distinguishing feature of positivists is consequently that they preach and practice a form of 'monism': the foundation of the law lies in the source; law is binding because it is formally enacted. Another distinctive feature of positivism - and we will return to this below - is to reduce the phenomenon that is law to certain features giving expression to that law. These features are procedure and form. All the other questions are expelled into the outer darkness of the non-legal. Questions as to the foundations and basis of law, as to its sociology, as to the theory of legislation, as to legal values, and so on, are all excluded from the jurist's purview. All he has to do is to analyse and systematise positive data through his application of rigorous exegetical methods that are designed to preserve a separation of powers between himself and the all-powerful legislator. The rest is a matter for the political scientist and the philosopher.

These theoretical premises entail various consequences. First of all, positivism presupposes the existence of a legislator, and therefore presents itself, par excellence, as a system in which law is the creature of the State. It hardly seems necessary, in this context, to point out that the most determined positivists have denied the very existence of international law. Secondly, positivism submits to State power in a manner which promotes no possibility of counter-currents, or of directing, tempering or restraining the way State power is used. The legislator (or constituent power) is all-powerful, or at least subject to no constraint whatsoever except the 
factual limits of its own political power. Its all-powerful will is subject to no limitation. Having expelled everything from the law that is extraneous to the systematisation of the States' legislative products, positivism does not even provide the State with any instruction or doctrine as to the act of legislation itself: it does not attempt to explore either the content of certain legal values or the ways in which they may be carried into effect. Legally, superior considerations of reason, justice, public utility, and the ends and objectives proper to mankind, are left out of legal account. Since will is the sole source of law, law is in fact merely power, and the applicable motto is justum quod jussum; auctoritas, non veritas facit legem. ${ }^{8}$ In this way, when it comes to the two essential values of law, justice and legal certainty, positivism ignores the former and gives entire allegiance to the latter. In this respect, its reductionism is striking. Finally, one must add that, for many positivists, the law as a system is not materially complete. Wherever the will of the legislator has omitted to create a norm, there is simply no law, and one is left in a legal void. At this point there is perhaps a possibility of applying the principle of 'residual liberty', according to which the citizen is free to do as he pleases provided only that he does not break the law, i.e., everything which is not forbidden is permitted. This gives such positivist currents a liberal touch. But in any event, in positivist thinking the phenomenon that is law is, so to speak, 'archipelagised', fragmented into numerous norms which, although they have all been legislated for according to the due forms, are weak as regards what they have in common. How, indeed, could it be otherwise, when positivist methodology is so disdainful of the 'general' (essence) and professes to recognise only the 'particular' (act)? Summing up, as J-L. Ortolan ${ }^{9}$ so pithily observed, the essence of positive law resides in power. Is it surprising, then, that the principles governing the idea of a State ruled by law were developed not by legal positivists but by the highly ideological natural law school of the Enlightenment?10 In reality, the principles that define a State subject to the rule of law arise, not from power, but precisely from efforts to control and limit it.

Given the experience of twentieth century totalitarianism, and its perversion of law on a scale hitherto hardly imaginable, ${ }^{11}$ it is no easy

\footnotetext{
8 Hobbes, Leviathan (1668), chap. XXVI.

9 Cited by E. Creasy, First Platform of International Law, London, 1876, p. 14.

10 Cf. H. Coing, Die obersten Grundsätze des Rechts, Heidelberg, 1947, pp. 150 et seq.

11 Cf. The classical treatment by F. von Hippel, Die Perversion von Rechtsordnungen, Tübingen, 1955.
} 
matter to accept a doctrine which - in its pure form - bases the duty of obedience to law solely on the arbitrary legislative competence of those who are in power. It is important to give full recognition to the fact that legal positivism, in the strict sense, necessarily implies unconditional obedience to the legislator's will whenever expressed in the proper form. Whoever denies that dogma is no longer a positivist in the exact theoretical sense of the term, because, by necessary implication, he is having recourse to considerations or values of an extra-positive nature to set bounds to the duty of obedience. The ultimate basis of law will then shift in the direction of such considerations or values.

So far as law is concerned, positivist doctrine in the strict sense existed only on the European continent, to the exclusion of the common law countries. The constitutional balance in the United Kingdom, and the powers of its great judges, together with the UK's more pragmatic tradition, prevented the spread of the voluntarist positivism of the continental civil law States. One has only to think of the conception of 'reasonableness', which has always been a source of the law as administered by judges in English-speaking lands. It can certainly be said that, in the common law system, the foundation and the sources of law have remained closely connected together. Nevertheless, although intellectually the focus might be on positive law, the role of values, as the foundation of law, has never been seriously disputed. Furthermore, the liberal tradition, which has so strongly formed and moulded the UK's remarkable constitutional order, has always solidly maintained the rule of law, and has spared 'positivist' tendencies within its legal systems from discredit.

We must be careful not to confuse 'positive law' (and the method of analysing law), itself a technical term designating the law that is in force at any given moment, with the philosophico-juridical term 'positivism', which attributes absolute authority to the legislator's will if the latter is expressed in the proper form. The term 'positive law' dates from mediaeval times, and was used by Abelard in particular. ${ }^{12}$ It carried with it no implicit or explicit judgment as to the basis for the validity of its norms.

12 On the origins of the expression 'positive law', cf. S. Kuttner, 'Sur les origines du terme droit positif', Revue historique de droit français et étranger, vol. 15,1936, pp. 728 et seq. 


\section{SOCIOLOGICAL DOCTRINES}

The causative methodology characteristic of positivism reaches its ultimate development in sociological doctrines of law, which thus present themselves as a form of 'achieved positivism'.13 At the same time, however, they take their distance from some of its dogmas. They refuse to see the law as an artificial phenomenon created by the exercise of any kind of will that can be identified with the State or even hypostatised in it. Law predates both the State and its sovereign will. It is a social product, formed through the spontaneous interaction of social forces. All the legislator does is to recognise it; he does nothing to create it. Here, then, attention shifts to the effects of social behaviour.

Sociological doctrines can be presented in a relatively objective light, or alternatively a relatively subjective one. Objective sociological theories place emphasis on the regularity and external effectivity of different kinds of behaviour. Here one ends up with the legal realism of $\mathrm{O}$. W. Holmes ${ }^{14}$ or the Uppsala School. ${ }^{15}$ The law is presented as an agglomeration of social facts, becoming law under the threat of sanctions. There are also doctrines such as the social solidarity conceptions promoted in France by L. Duguit: ${ }^{16}$ in these, the law is a product of the material interdependence of social forces, the people, etc. By contrast, subjective sociological theories emphasise the conscience or legal conviction animating social forces. The law is that which is socially recognised as

13 See e.g., J. Stone, The Province and Function of Law, Cambridge (Mass.), 1950, pp. 391 et seq.; J. Stone, Social Dimensions of Law and Justice, Stanford, 1966 , pp. 35 et seq. For further bibliographical indications, see below, chap. 5.

14 On the American Legal Realism, see e.g., G. A. Aichele, Legal Realism and Twentieth-Century American Jurisprudence, New York/London, 1990; M. Martin, Legal Realism, New York, 1997; J. H. Schlegel, American Legal Realism and Empirical Social Science, Chapel Hill/London, 1995; and also M. A. Rea-Frauchinger, Der amerikanische Rechtsrealismus, Karl L. Llewellyn, Jerome Frank, Underhill Moore, Berlin, 2006. For a good short account of the position of O. W. Holmes, see G. Fassò, Storia della filosofia del diritto, vol. III, Rome/ Bari, 2001, pp. 258 et seq.

15 On the Scandinavian Legal Realism, see H. H. Vogel, Der Skandinavische Rechtsrealismus, Frankfurt a. M., 1972; E. Pattaro, Il realismo giuridico scandinavo, Axel Hägerström, Bologna, 1974, S. Strömholm/H. H. Vogel, Le réalisme scandinave dans la philosophie du droit, Paris, 1975; S. Castiglione, Il realismo giuridico scandinavo, Florence, 1977; J. Bjarup, Skandinavischer Realismus, Munich, 1978; L. L. Hierro, El realismo juridico escandinavo, Valencia, 1981; for a synthetic account, Fassò, ibid.

16 See infra, chap. 5.A). 
being law. External conduct is replaced in these theories by an element of consciousness, whether the latter is seriously intellectual or of a more diffuse nature. Subjective sociological theories have been particularly strong in Germany, represented in the thought of the celebrated E. Bierling and G. Jellinek. This more subjective German sociologism has led, through the work of E. Ehrlich and M. Weber, to theories which emphasise the fact that a norm can impose itself on a society and be recognised by it.

This second generation sociologism opens the door to State power and thus leads back towards positivism. By contrast, the opposite might be said of the early twentieth century French school, which postulated a strictly objective sociologism. This attitude developed against the background of the struggle with the Jacobin concept of the all-powerful State. The tendencies of the resulting sociologist doctrines - influenced by L. Duguit - were anti-State and pro-liberal, bringing the law back to the interactions of individuals, free from the State's oppressive yoke. Any attempt to pull together theories with such disparate results into a single embrace therefore calls for a noticeably nuanced approach.

The origins of the sociological doctrines are relatively recent. They emerged in the wake of the anti-rationalist reaction against abuses of the deductive method which had been promoted earlier by the Enlightenment school of natural law. In place of that school's emphasis on the unity of abstract reason, the early nineteenth century saw a trend to substitute for it the diverse historical experiences of the various nations. Law was now to be linked to the lived experiences of the various peoples. In the process of giving expression to those experiences, law was, of necessity, multiple, diversified, and local. It was no longer to be based on the abstract unity of reason stressed by the Enlightenment's school of natural law. The void left by the rejection of rationalist natural law had been filled by the State positivists from above, with the will of the ruler. In contrast, the sociological theorists attempted to fill it from below: they constructed law as the product of social forces.

The sociological theories' common ancestor was Savigny's historical school of law. That school was politically conservative, opposed to the modernising codes of the liberal State, and saw law as indissolubly linked to the national culture of the people concerned at any given moment in time (the Volksgeist). The school deliberately took up a position opposed to that of the natural law school, which had been in quest of objective law, based on the common rationality of mankind, one 
that was valid for all peoples and all time. ${ }^{17}$ In contrast to that, here the law was configured as a permanent work in progress, emerging from the inner depths of a nation's history, and presenting itself in the garb of customary law. It resulted from the action of deep and invisible social forces. These sociological schools therefore claimed, like the positivists, that laws are always particular to the human society in which they operate, and that there is no universal law applicable to all mankind.

On what, then, is this law based? There is no reason to look for any justification other than the very existence of the people or nation, with its own culture and society: ubi societas, ibi jus. A feature common to the various branches of the sociological school is that they make a very close connection between, on the one hand, the basis or foundation of law, and, on the other, its sources. The mere fact that society exists in itself legitimises all the rules society creates and imposes as laws. According to this way of thinking, the asking of a further question, free-standing in nature, as to the basis or foundation of those rules, is simply senseless. In this respect, the sociological doctrines are similar to the positivist ones: there is 'monism' between the sources and the foundation. Nevertheless one is entitled to ask why everything that de facto emerges commands obedience. How can this huge leap from is to ought be justified? None of the sociological or positivist theories has come up with a satisfactory answer to this question. In flat contradiction to its anti-metaphysical stance, what the sociological school in fact depends upon is an extremely disputable dogma about the radical unity of everything that is with everything that ought to be. This conception not only disallows all criticism, but is opposed by one of the most intimate convictions of the human mind, namely that no accomplished fact bears within itself its own justification. As phenomena of that which is real - and so at the level of sources - facts cannot be ignored. But equally, they cannot in and of themselves claim to dispose of the foundation question. Every law implies the existence of a duty - the imperative 'Thou shalt' (in the sense of 'should', or 'ought to'). The fact that one is constrained or obliged to comply belongs to the world of causation, compliance here being something that one must do: it is not something one should do. The existence of sanctions or constraints may explain why one must obey (and one can indeed leave it at that, like the Uppsala School), but it cannot explain why one ought to do so. The ought depends on a value of some kind. If we want to escape from the tyranny of simple facts, from

17 On this issue, see generally J. Llompart, Die Geschichtlichkeit der Rechtsprinzipien, Frankfurt a. M., 1976. 
the monstrous determinism of the world of causality, there is no way of avoiding some reference to values. This, however may, at least in some senses, open the way back towards moderate doctrines of natural law.

\section{NATURAL LAW DOCTRINES}

In speaking of natural law doctrines, the use of the plural is more essential than in the other cases. ${ }^{18}$ There is no single such doctrine: on the contrary, there are a great number of them. In broad terms, one might argue that practically all thinking about law between Antiquity and the nineteenth century was based at least partially on 'natural law'. In that sense, what we might call 'jurisnaturalism' was the common receptacle into which the philosophy of law was continuously poured from Antique times until the victory of positivist tendencies in the nineteenth century. The very numerous answers given over this extremely long period to the question of what obligations are incumbent upon mankind in its creation and administration of law usually involved those concerned in using the expression 'natural law': perhaps unsurprisingly, therefore, the very frequency with which the term has been used has been, and still is, the source of all kinds of confusions. For a start, the word 'natural' itself is highly ambiguous, further accentuating the difficulties. Sometimes it is elevated into the idea of an ethical cosmos (nature in the transcendental sense), and at other times reduced to the observation of the causative forces of what we think of as the real world ('nature' in the empirical sense). The development of natural law was thus complicated by divergent tendencies in interpreting the word 'nature', tendencies which were particularly acute in Antiquity and in the period of the Enlightenment. On the one hand one finds spirit-based and idealistic doctrines of natural law, seeking support from such values as justice, reason, and the fact that man is a social animal. These doctrines gave rise to the conception of an ideal law, as opposed to positive law. On the other hand, there were existentialist and empirical doctrines of natural law, in which law was based on the realities of nature. Here, centre-stage was taken by instincts, the impulse to self-preservation, the law of the strongest and the struggle for existence. In this field a common thread runs from the Sophists to Hobbes, Spinoza, and onward to Schopenhauer and Nietzsche. In the former case, 'nature' is an ethical concept ('being' in the transcendental sense), and in the latter an empirical one ('being' in the causal sense).

18 For a bibliography on natural law, see below, chap. 6 . 
From the work of Hobbes onwards, everything conspired to drive this existentialist current towards positivism and modern theories of power. The concept of natural law was thereafter identified exclusively with the 'spiritual' conception.

The search for a common thread among the various natural law doctrines leads us to the following considerations. Natural law is concerned with those elements of law which are prior and external to the voluntary and social activities of mankind, elements whose authority is derived simply because they are somewhere 'given' (Vorgegebenheiten). This is just as true of the more spiritual natural law doctrines as it is of the more empiricist ones, reflecting the duality discussed above in the meaning of 'nature'. What the more spiritual theories - which have been the dominant ones in the past and are often spoken of tout court as the natural law doctrines - have in common is that they seek the ultimate foundation of law in a transcendent idea representative of a supreme value: God, justice, the common good, or the idea of Man as subject to fundamental moral and physical imperatives. All these doctrines therefore refuse to see the fundamental basis of the phenomenon that is law in the uncontrolled will of a person or entity invested with legislative power, whether the latter is exercised in a formal manner (positivism) or an informal one (sociologism). The dogma voluntas quia voluntas facit jus is rejected. Similarly, these doctrines all refuse to accept that the basis of law can be found simply in the raw facts and effectivities of Man's social existence. According to natural law thinking, a legal order of things cannot issue from a single will or single fact. Of course, a system or order that amounts simply to the application of constraint can be useful, if only to keep the peace. ${ }^{19}$ But for a positive order to be a legal one, with a proper foundation, and not just a system of constraints, to be in fact an order that commands obedience in the profound sense of the word, it needs a higher sanction than either the will of the legislator or the sociological facts. Where, then, is this higher sanction to be found? Where do we look for this philosopher's stone? At this point, natural law turns to values. The highest value in this field is justice. So the legal order must serve or tend towards justice as its supreme value. It is here that we find the 'objective' character of natural law doctrines.

19 St. Thomas Aquinas (Summa theologica, II, I, 96, 4) argues that even an unjust law must nevertheless be obeyed, for reasons of legal certainty and security, provided that it does not violate certain absolute precepts of divine law (lex divina). In passing, therefore, Thomas recognises that there has to be at least a minimal level of 'value' even in a mere order of constraint. 
The common root of natural law doctrines is therefore not, as is so often assumed or claimed, the idea of a law valid for all mankind and in all times. That idea, with its civilising effects, did prevail when natural law thinking was dominated by developing rationalist elements, in the Stoa and in the Enlightenment. But that is only one mode of natural law thinking, associated with some natural law doctrines, but not with others. Thus, both when, in the high mediaeval period, St. Thomas Aquinas argued that the nature of Man, and thus natural law itself could vary ('natura autem hominis est mutabilis' ${ }^{20}$ ), and in modern times, ${ }^{21}$ markedly more individualised and specific types of natural law have sometimes been argued for. One can therefore speak of certain principles or categories of law which, according to natural law doctrines, must necessarily apply throughout time and space. But then their number is severely restricted, and they do not present themselves as an autonomous legal order.

The very idea of natural law is an eternal one, because it corresponds to a fundamental need of the human spirit. Mankind, faced with the world it experiences through its senses, has to be able to turn to an idea of justice, without invariably being forced to bend the knee before faits accomplis and other constraints imposed by the powerful. In this respect, natural law accommodates elements both of the instinct to fight and the instinct to reach an accommodation. That is meaning of the Antigone drama. As Nicolas Politis put it, in a book he wrote shortly before his death, when the world was suffering the fearsome torments of war:

When, in any human society, rules of positive law become either inoperative or arbitrary as a result of the inadequacy or over-development of authority, the people's unfailing feeling for justice brings them to lift their gaze and seek a kind of salvation from superior and permanent precepts, what the ancient Greeks called unwritten law [our translation]. ${ }^{22}$

It is all very well to proclaim the death of natural law, but the fact is that it is always there, even if on the back-burner, awaiting the hour of its recall to the consciences of the human race.

\footnotetext{
20 S.T., II, II, 57, 2.

21 For example, through the doctrine of natural law with variable content, i.e., as form of justice, which is found in Stammler. Cf. R. Stammler, Wirtschaft und Recht nach der materialistischen Geschichtsauffassung, 4th edn, Berlin, 1921, p. 174.

22 N. Politis, La morale internationale, Neuchâtel, 1943, p. 7.
} 
It seems appropriate to close this brief explanation of theories of natural law with indications as to how they have operated historically. They have indeed played a part throughout the history of western legal thinking.

(a) In ancient Greece, the concepts of law and justice were born of the idea of a cosmos ordered by the Gods. Little by little, the Greeks, a people characterised by both cognitive optimism and intellectualism (i.e., according primacy to reason over will) gradually rationalised their cosmos. In consequence, the natural law concept emerged. Law belonged to the natural order of things, which could be known by the exercise of reason. Since law was inherent in things, and in the order of things, it presented itself as a 'given', and not as a human creation. These ideas were brought to their apogee by the Stoa, from whence they passed to the Romans (Cicero, Epictetus, Seneca and Marcus Aurelius), the associated doctrines forming the basis of the universalist Roman conceptions of jus naturale and jus gentium.

(b) Next, we have the natural law of mediaeval Christianity, a concept which oscillated between voluntarism and rationalism. Jewish and Christian culture had a different basis from the intellectualism of Greek thought. The latter had based itself on the equation: being = rational order $=$ knowable to man. Christianity, by contrast, is initially dominated by voluntarism anchored in the impenetrable commandments of God. These place a screen between this present world and the Beyond. A veil is thus drawn over reason, the full enjoyment of which is denied to mankind because of Original Sin. Man is no longer in possession of knowledge: he must do what God tells him. In this context, the tendency was for natural law to turn into positive law dictated by the Divine Will, and here we instinctively call to mind the tribulations of Job, the sacrifice of Isaac (akedah), and the union of Hosea and the prostitute. God's freedom is absolute and totally unfettered. But Man can nevertheless be sure of divine justice, anchored as it is in the love and compassion of the Almighty. This is the theology of St. Paul, of the Franciscans, of Victorinus, St. Augustine, Duns Scotus, William of Ockham, and later of Luther and Calvin. Universalism and reason give way to the individualisation of Will. The centre of attention is now the unique destiny of each individual before God, and the individual's loving response to the creator. The generalisations of reason, being strangers to the action of faith, are pushed aside. Natural law is metamorphosed into the dictates of the divine will to the heart 
and soul of the believer. This process naturally makes it more subjective.

Faced with this voluntarist current of opinion, and naturally mistrustful of States and their institutions, St. Thomas Acquinas revived the rationalist tradition of ancient Greece, integrating it into the Christian model of belief. In effect, St. Thomas affirms the primacy of divine wisdom rather than the unfettered will of God. This way of seeing things was to be further developed by G. da Rimini and by the Spanish scholastics (Vitoria, Molina and Gabriel Vasquez). In their view, natural law involves the participation of Man in the 'finalist' order of the cosmos itself, and this brought them back to the Aristotelian tradition. Once again, natural law had resumed its place as the expression of a universe that is ordered right up to its supreme and ultimate finality. So the tensions between reason and will, between heaven and earth, between the justice of this world and the justice of God, are relaxed. Here, then, we have a gigantic edifice designed to bring harmony to the concept of natural law; eight centuries later, it still commands our admiration.

(c) Next we have the natural law of the Enlightenment Period, which is also often called the 'Age of Reason'. The period featured a range of modern constitutional movements, which gave its natural law doctrines quite a political character: absolutism (Hobbes), liberalism (Locke), and democracy (Rousseau). The thinkers of the day drew on the methods of the natural sciences to deduce a complete system of norms. The search was on for a detailed and complete legal order that could be derived by simple deduction from a number of supreme principles that were thought to represent the 'true' nature of Man. Usually the thinking was as follows: since reason is given to everyone in common, the resulting law is necessarily both universal and immutable. This thinking led to the development of enormous speculative systems, whose conclusions were dictated by the particular combinations of first principles selected. Examples of the first principles were suum cuique, honeste vevere, neminem laedere, pacta sunt servanda, sufficientia vitae, homo animale sociale, tranquillitate civitatis, securitate, quod vis ut alii tibi faciant tu et ipsis facias, etc. These deductive systems resulted from 'laicising' the conception of law. They were attempts to derive a complete legal order exclusively through rational deduction. The method reached its apogee in Leibniz's Nova methodus discendae docendaeque jurisprudentiae (1667), and 
then in his followers, such as C. Wolff. ${ }^{23}$ Nowadays, the most frequent criticisms of natural law tend to refer, often simply by implication, to the deductive natural law of the Enlightenment period. But that period was, nevertheless, only an episode in (not to say avatar of) the concept's long history.

(d) Modern trends in natural law reject the idea of deducing a complete and immutable legal system exclusively through the workings of human reason, and instead accept the historical contingency of law. They emphasise the importance of changing cultural, social and political factors. Quite naturally, they have all concentrated their efforts on the supreme principles of justice as the general context in which positive law can be developed. For thinkers of this kind, it is a matter of identifying the 'just law' applicable to a given social context in the here and now. Some of them concentrate exclusively on form (R. Stammler ${ }^{24}$ ), others on content (H. Coing 25$)$; some doctrines are inspired by Christianity (L. Taparelli, ${ }^{26}$ J. Ellul, ${ }^{27}$ E. Brunner ${ }^{28}$ ), often tending to exaggerate the importance of the natural 'given' as compared with the positive 'construct'; other less ambitious doctrines are secular in their inspiration (H. Coing, ${ }^{29}$ R. Marcic, ${ }^{30}$ H. Ryffel, ${ }^{31}$ and G. del Vecchio ${ }^{32}$ ).

What all these theories have in common is the attempt they make at a synthesis between the contingent and the necessary. If the necessary has to be reduced to a minimum so as not to have stifling effects, the contingent, for its part, cannot be absolute, because that would mean the end of civilisation. First of all, there are contingencies, and thus the domain of liberty. Liberty is a value which allows mankind to realise its potentialities. Since human awareness is necessarily only partial, relative, uncertain, and circumscribed by time and space, a complete system of natural law is impossible. It follows that the act of generating law adequate to the needs of changing social conditions must, to a very

\footnotetext{
23 Cf. B. Winiger, Das rationale Pflichtenrecht Christian Wolffs, Berlin, 1992.

24 Lehrbuch der Rechtsphilosophie, Berlin/Leipzig, 1922.

25 Coing, supra note 10.

26 Saggio teoretico di diritto naturale, 6th edn, vol. I-II, Palermo, 1857.

27 Le fondement théologique du droit, Neuchâtel/Paris, 1946.

28 Gerechtigkeit, Zurich, 1943.

29 Coing, supra note 10.

30 Rechtsphilosophie, Freiburg i. Br., 1969.

31 Rechts- und Staatsphilosophie, Neuwied/Berlin, 1969.

32 Lezioni di filosofia del diritto, Milan, 1963; La giustizia, Rome, 1946.
} 
considerable extent, be left to the forming and un-forming of opinion; and that is the positive law element. Nevertheless, according to these doctrines, mankind is not in a position to decide everything, to dispose of everything. This is the key concept underlying modern natural law thinking: there are facts that are withdrawn from the arbitrary disposal of human beings. This 'undisposable' element is constituted first and foremost by the very idea of Man, both in itself - in his individual finality (the fundamental rights of Man) - and in his social being (the common good, equality, and justice). Natural law is therefore never an autonomous system of law. It contains only a few supreme principles of justice - for the purpose of avoiding what one might call a legal reductio ad hitlerum - and consequently it presents itself as an open-ended and indeed fragmentary system, one which, at every point, seeks and needs the functioning of the order of positive law. The functions of natural law are thus to provide the framework into which positive law slots, to confront positive law with certain inescapable requirements, and to give it direction by providing it with a source of inspiration. ${ }^{33}$ To paraphrase Dag Hammarskjöld, one might say that the objective of this relatively 'tame' natural law is not to propel mankind into paradise, but rather to avoid its descent into hell.

\section{$* * *$}

What is the basis and foundation of the phenomenon that is law? Manifestly, each one gives the answer one prefers, whether based on positivist, sociological, or natural law. Whatever else one can, we can at least be sure of this, that ultimate knowledge of what is the basis or foundation of law is not possible in the same sense that knowledge of facts is possible, because the question is essentially transcendent or metaphysical. The ultimate validity of positive law ultimately lies, of necessity, outside it. As Kant showed, theoretical reason cannot reach any certainty when it goes beyond the facts of experience. Must we then resign ourselves to stopping short at this point? Kant says no. He accepts the primacy of practical over 'pure' (theoretical) reason. This amounts to saying that, to the extent that questions cannot be the subject of certain knowledge - and every theory (including positivist theory) contains such

33 One has often to resort to negative philosophy. The negative concept of injustice enables us to conceive of justice as a positive element: when one senses an injustice one can begin to grasp what justice means. This is an ancient idea: Fragment no. 23 of Heraclitus (c.500 BC) says that, were it not for the existence of injustice, men would not understand the word 'just' (or 'law'). 
aspects $^{34}$ - certain 'given' data have to be postulated at a practical level when they are necessary in order that we can live a good human life. I do not know whether there is any such thing as objective justice, but what I do know is that it is better to postulate some form of its existence as a necessity for the better functioning of human society. I do not know whether human beings are free or unfree; but it is better to affirm that they are at least partially free, because that affirmation is essential to the fulfilment of the individual and of society as a whole.

It follows that the standard for testing the truth of a theory is not to be found in that theory's premises. Rather, it is to be found 'downstream', in its consequences. As the logician Charles Sanders Peirce penetratingly observed, the value of a theory is to be known by its fruits. ${ }^{35}$ Applying these considerations to the question of the foundations of law, it seems to us to follow, almost by a process of elimination, that the most satisfying theories are the most moderate ones. The definition of their content is necessarily incomplete, evidence itself of mankind's struggle for law, in which it fulfils part of its worldly destiny. If one asks why these doctrines are the most satisfactory ones, the answer is that they alone are presented as attempting in themselves to construct a harmonious synthesis between a small kernel of objective necessity and a large outer shell of subjective liberty. ${ }^{36}$ Amongst all the theories, this is the only one that is a self-limiting theory. Positivism is not such a theory, because if ever it admits a criterion going beyond the all-powerful Will of the legislator, it abandons its own premises, accepting a metaphysical criterion incompatible with its starting point. It is much the same with sociologism, which has to recognise the determinative force of societal facts, whatever their nature. As soon as it tries to evaluate such facts by a criterion which is external to the realm of fact, it abandons its fundamental sociological terrain. In light of what we have said so far, we should make it clear that we do not assert that 'positivist' or 'sociological' doctrines are unable to develop more 'measured' variants. Obviously it is indeed possible to enrich 'positivism' by applying certain ethical limits, just as it is possible, by similar means, to limit the all-embracing power of sociological facts. But, and this is the essential point, when that step is taken, a natural law criterion is introduced into these 'alternative' doctrines. What then

34 Thus the fact that Will alone creates law, that the form must prevail over the content, and that the existence of law and the duty to obey it are separate or identical, are not facts of experience: they are postulates.

35 C. S. Peirce, Collected Papers, vol. V, Pragmatism and Pragmaticism, Cambridge (Massachusetts), 1965, pp. 1 et seq.

36 See infra, chap. 7.B.2. 
emerges is a synthesis: a doctrine balanced between objective facts, metaphysics, and subjective facts, whether voluntary or otherwise. And what, in fact, is such a synthesis if not a doctrine corresponding exactly to the efforts at harmonisation undertaken by modern schools of natural law? Certainly, one may speak of 'moderated positivism', and thus spare oneself the pain of speaking of 'moderated jurisnaturalism': but one has to recognise that, in essence, it is the same thing. If that is true, then we can say that the positivist and sociological theories have been enriched by natural law elements when issues of the foundation of the law are concerned.

What we have been saying as to the law in general applies equally to international law in particular. The characteristics of international law its universality, its lack of formalism, and the rationality with which it has been constructed since Roman times - have always led to its seeking direct accommodations with the ideas of justice and equity. It is generally appreciated that the jus gentium was connected to the jus naturale, giving universal expression to the latter in the 'positive' law context. It should be added that positivism presupposes, in order that it may function correctly, a much denser level of legal activity than can be found in the international context: in particular, it presupposes regular operations by a legislator. It is far from obvious that these conditions are satisfied within the international community itself. Thus, even the positive law tends to be handled with some flexibility in such a system, based on various flows of demands and responses in the shaping of the law. On the other hand, the sometimes rather extreme pluralism characteristic of international life makes it more difficult than in any other context to base the applicable law on values, on justice, and on the idea of natural law. The question 'What justice?' immediately comes up. Is it to be western justice or third world justice, the justice of the USA and its investors, or that of the 'exploited' people of Chile under Salvador Allende? How, and in the name of what, is one to judge? In other words, the task is more difficult in international law than in any other context, because the common cultural and political underpinnings are so much smaller. 